\title{
High Times for U.S. Employees: Human Resource Management Considerations in Addressing Marijuana Legalization in U.S. Organizations
}

\author{
Wendy N. Buice, MSML ${ }^{1}$, \& Steven V. Cates, DBA ${ }^{2}$ \\ ${ }^{1}$ Purdue University Global, United States \\ Correspondence: Steven V. Cates, Purdue University Global, United States.
}

Received: September 29, 2021

doi:10.11114/aef.v8i6.5397
Accepted: October 27, $2021 \quad$ Available online: November 5, 2021

URL: https://doi.org/10.11114/aef.v8i6.5397

\begin{abstract}
Recent changes in state laws have legalized marijuana use for their state citizens. Originally by 2016, twenty-six states, the District of Columbia, and Puerto Rico had legalized marijuana for medical use (State Medical Marijuana Laws, 2016). In the 2020 elections eighteen states, two U.S. territories, and the District of Columbia legalized recreational use of cannabis. We now have thirty-six states, four U.S. territories, and D.C. who have legalized medical use of the drug use (State Medical Marijuana Laws, 2021). This however creates some major issues for Human Resource professionals due to the fact that federal law still considers marijuana use illegal. This creates a confusing situation for organizations and especially Human Resource professionals who must create and enforce policies on the use of prescription and non-prescription drugs within the work environment. The purpose of this research is to determine if medical marijuana should be protected in the workplace and under what conditions. Based on the literature three research questions were posed and three hypotheses were tested based on analyzing data from a survey questionnaire that was completed by 57 working adults. Results indicate that they support the use of medical marijuana as a viable medical treatment and companies should recognize and support this medical remedy. Results indicate employees should be protected in their use of marijuana under the FMLA. Results also indicate marijuana should also be considered for long-term and permanent illnesses under the ADA. Implications are employees see marijuana in a positive light, as a viable medical treatment, and expect human resource management to support policies that allow for use of marijuana.
\end{abstract}

Keywords: Human Resources Management, Marijuana, U.S. Federal Law

\section{Introduction}

With the changing environment as it relates to marijuana use in the United States there is an increased need to understand not only the implications in society but also how to handle this from an HR perspective in organizations. In the federal and state elections held in November, 2020, there were many ballots where either the issue of recreational or medical use was placed on the ballot for vote. We have increased from twenty-six states, the District of Columbia, and Puerto Rico to thirty-six states who have legalized marijuana for medical use (State Medical Marijuana Laws, 2021) while the drug is still not legal under federal law. This creates the need for research and application about how human resource departments will determine how to manage those individuals taking advantage of their state law allowances use (State Medical Marijuana Laws, 2021).

Throughout the research attention must be paid both to the regulations but also to the protections that should be allowed to workers and the impact of those polices created by organizations in attempting to comply with state law while being in non-compliance with federal law. It is important to create policies that ensure that those workers are employed in a safe environment and that there is also clear understanding on the interpretation and administration of the policy.

One key thing to consider no matter the legality of the state is that, "although state laws vary, what is true in every state is that these laws don't require employers to permit drug use in the workplace or tolerate employees who report to work under the influence, according to Ingrid Fredeen, J.D., vice president of advisory services at NAVEX Global" (SHRM, 2014).

\section{Statement of the Problem}

Given that thirty-six states have passed legal use of marijuana in some form what protections do those state's citizens 
have from federal prosecution under federal law? If state general statutes provide for the medicinal and or recreational use of marijuana are employees protected under legal protections and how does this impact the administration of federal acts such as the Federal Family and Medical Leave Act (FMLA) and the Americans with Disabilities Act (ADA), for medicinal use of marijuana during employment?

\section{Literature Review}

The legal history of cannabis in the United States pertains to the regulation of cannabis (legal term marijuana or marihuana) for medical, recreational, and industrial purposes in the United States. Increased restrictions and labeling of cannabis as a poison began in many states. The Pure Food and Drug Act was passed by the United States Congress in 1906 and required that certain special drugs, including cannabis, be accurately labeled with contents. From 1906 onward, there were increased governmental regulations and outright prohibitions in the 1920s.

The Uniform State Narcotic Drug Act, first tentative draft in 1925 and fifth final version in 1932, was a result of work by the National Conference of Commissioners on Uniform State Laws. It was argued that the traffic in narcotic drugs should have the same safeguards and the same regulation in all the states. The committee took into consideration the fact that the federal government had already passed the Harrison Act in 1914 and the Federal Import and Export Act in 1922. It was assumed the Harrison Act was all that was necessary. The Harrison Act, however, was a revenue-producing act and, while it provided penalties for violation, it did not give the states themselves authority to exercise police power regarding seizure of drugs used in illicit trade, or about punishment of those responsible. The act was recommended to the states for that purpose. As a result of the Uniform State Narcotic Act, the Federal Bureau of Narcotics encouraged state governments to adopt the act. By the middle of the 1930s all member states had some regulation of cannabis (usgov.org, 2018).

By the mid-1930s cannabis was regulated as a drug in every state, including 35 states that adopted the Uniform State Narcotic Drug Act. The first national regulation was the Marihuana Tax Act of 1937 (usgov.org, 2018).

Despite medical cannabis laws in 46 states cannabis is still not legal under federal law. The federal government regulates drugs through the Controlled Substances Act of 1970 (CSA) (21 U.S.C. § 811), which does not recognize the difference between medical and recreational use of cannabis. These laws are generally applied only against persons who possess, cultivate, or distribute large quantities of cannabis. Federal law, for the most part, is clear on the topic of marijuana which is a prohibited drug.

Since 1970 marijuana has been a DEA Schedule I substance, meaning that in the view of the federal government, it's as dangerous as LSD, heroin, and Ecstasy, and has 'no current accepted medical use and a high potential for abuse (Dean, 2018).

Multiple efforts to reschedule cannabis under the CSA have failed, and the U.S. Supreme Court ruled in United States v. Oakland Cannabis Buyers' Cooperative 532 U.S. 483 (2001) and Gonzales v. Raich 545 US 1 (2005) that the federal government has a right to regulate and criminalize cannabis, even for medical purposes

Though all marijuana use remains not legal at the federal level President Barack Obama's administration issued the Cole memo in 2013, which shifted the U.S. Justice Department's (DOJ's) enforcement priorities away from prosecuting adult marijuana users who are complying with state law. (Nagele-Piazza, 2018c).

On August 29, 2013 the Department of Justice (DOJ) issued a guidance memo to prosecutors concerning marijuana enforcement under the Controlled Substance Act (CSA) making it clear that prosecuting state legal medical marijuana cases is not a priority. The memo included eight guidelines for prosecutors to use to determine current federal enforcement priorities. Fortunately, most medical cannabis program's regulations require the same guidelines ensuring that any business with a license is meeting these requirements as well. These guidelines include: 1. Preventing of distribution of marijuana to minors. 2. Preventing revenue from the sale of marijuana from going to criminal enterprises, gangs or cartels. 3. Preventing the diversion of marijuana from states where it is legal under to state law in some form to other states. 4. Preventing state-authorized marijuana activity from being used as a cover or a pretext to traffic other illegal drugs or other illegal activity. 5. Preventing violence or the use of firearms in cultivation and distribution of marijuana. 6 . Preventing drugged driving and the exacerbation of other adverse public health consequences associated with marijuana use. 7. Preventing the growing of marijuana on public lands and the attendant public safety and environment dangers posed by marijuana production on public lands. 8. Preventing marijuana possession or use on federal property.

As of 2016, several federal agencies have issued guidelines and other policy memorandums to manage the conflict between federal and state laws as they pertain to medical marijuana.

On May 8, 2018 H.R. 5520, The VA Medicinal Cannabis Research Act of 2018 was reported favorably out of the House Veteran Affairs Committee. The bill, while limited in scope (it codifies the VA's ability to do research on medical cannabis) marks the first time a stand-alone cannabis bill has been reported favorably by a committee since the introduction of the 
Controlled Substances Act. The bill is currently awaiting being scheduled for a vote in the full House (usgov.org, 2018).

\section{Human Resource Management Implications}

From a human resources perspective there are practical and technical challenges to effective enforcement. State law can also complicate the element of testing and enforcement. Attorney Walter Stella expressed this concern related to recent changes in California law, California provides a constitutional right to privacy which restricts employers from monitoring off-duty conduct. (Nagele-Piazza, 2018a).

This could create random testing as being targeted. A situation could arise where one state allowed recreational marijuana use and an employer knew a set of employees visited that state over the weekend. The employer then selectively tests these employees upon returning to work from the weekend. This could be considered under current legal conditions as entrapment. Stella's comment on "off-duty conduct" as being protected under California law could then potentially provide a defensible argument for employee protection.

Smith, (2018) in quoting the Secretary of Labor, Alexander Acosta in 2018, states "Employers should think twice before drug-testing every job applicant"

This advice is what many companies already are following in light of the patchwork of state laws affording rights to medical marijuana users and increased use of pot.

Bell (2018) indicates drug testing for some professions such as pilots, nuclear power plant operators and public-transit drivers, may be mandated under federal law or federal contracts.

Attorney Michael Clarkson noted that Maine was the only state in the union, to date, that has enacted legislation that went as far as to provide recreational marijuana users protections within the workplace (Smith (2018).

Mechanisms to effectively test for marijuana use hinder human resource professionals trying to ensure a safe workplace while still ensuring compliance with state and federal laws. Marijuana is such a confounding drug that scientists and law enforcement are struggling to create an objective standard for marijuana intoxication (Simon, 2018b).

It should be noted that measuring blood content of a substance is not equivalent to intoxication. Hound Labs CEO, Mike Lynn indicates they are not measuring impairment. The breathalyzer is going to provide objective data that potentially confirms what the officer already thinks (Simon, 2018b).

Other factors related to the complexity of this issue to include: THC levels, CBD levels, tolerance, genetics, frequency or consumption, type of consumption, and type of drug itself (Simon, 2018b).

Testing may have adverse impacts on operational viability for an organization. Safety First, a drug-testing division of Behavioral Health Systems, has had clients remove marijuana from their testing panels as a direct result of changes in state law. In certain industries, such as hotel and hospitality, there is no implementation of marijuana-testing programs due to concerns that firing those who test positive would cause significant staffing issues (Smith, 2018). This is in stark contrast to industries such as transportation where zero-tolerance is still mandated by federal law under the Department of Transportation (dot.org, 2018).

Human Resource Management is responsible for insuring employee wellbeing within the workplace environment. It is important to remember no states statue forces employers to tolerate on-the-job use (Nagele-Piazza, 2018).

\section{Legal Implications}

The legal implications of marijuana use on the job are conflicting. Legal policy can be focused on laws on decimalization of marijuana use and laws focused on employment protection (JazzHR, 2017).

Due to the laws related to states' rights each state can have significantly diverse implementation causing conflicting regulations hindering human resource professionals from implementing clear guidelines within their organizations.

\section{Federal and Family Medical Leave Act and the Americans with Disabilities Act}

Even the FMLA and ADA, the federal workhorses of employee medical protections, do not protect medical marijuana use, possession, or impairment in the workplace. In almost every legal case to date, use while working remains a valid reason for termination.

However, in states where medical marijuana use has been legalized, if a condition requires an employee to take time off from work to use medical marijuana, that time off would in fact be covered by FMLA.

The answer to ADA coverage is "not likely" but is more complicated due to some individual state ADA statutes (Doherty, 2017).

What should be noted in most cases is both of these acts are federal and not state, and therefore, federal law presides in the interpretation of such cases. 
The following Table 1 provides the results of federal and state law concerning recognizing the use of medical marijuana.

\section{Drug Use Legislation in the US}

Organizations have varying areas on how to define their policy around drug use and the different ways to build drug use policy. According to the U.S. Department of Health and Human Services Drug-Free Workplace Programs, "Today, the concept of a Drug-Free Workplace has become the norm with large and medium size employers. Efforts are continually made by Federal, State, and civic and community organizations to bring the Drug-Free Workplace experience to a greater percentage of smaller employers" (Heathfield, 2016).

This means that the smaller organizations will look to larger companies to benchmark on the policies they have built and the issues associated with that policy. The executive order done by then US president Ronald Regan known as The Federal Drug-Free Workplace Program was initiated by Executive Order 12564 (Drug-Free Federal Workplace, 1986) which established the goal of a Drug-Free Federal Workplace and made it a condition of employment for all Federal employees to refrain from using illegal drugs on or off-duty. It established the Drug-Free Workplace policy and specifically stated that employees both "use of illegal drugs, impairs efficiency, undermines public confidence and makes it more difficult for other employees who do not use illegal drugs to perform their jobs effectively" (Heathfield, 2016).

Ultimately, we can see that the government believes that there are both relationships to drug use and the employees but also employees in the workplace who do not use. Defining this caustic relationship is critical to understanding how critical the policy and its protection must be for the organization.

The Drug-Free Workplace Act of 1998, required that federal workers agree that they would submit to a drug-free working environment and their employment be actually conditionally based on based on this agreement.

By 2003 the Comprehensive Dangerous Drug Act made it mandatory that any company with a minimum of 10 employees create policies around a drug free work environment. It is evident that the US government feels strongly that both federal and private companies have to work to create these policies related to drug use.

\section{Considerations for Drug Policy Creation}

Several considerations are needed to define a drug free policy in an organization. According to SAMHSA.org, policies are "legal requirements, goals, definition, benefits and then any consequences associated with non-compliance" (SAMHSA, 2016). First and probably most important is that you will want to research your specific state laws and then at a minimum be able to meet those requirements. This will include ensuring that there is clear communication to the staff and that an awareness program is created in order for employees to have easy access to services and treatment programs.

The creation of categories of those substances that will need to be addressed in the policy is also important and could include alcohol, tobacco and prescription drugs. This is the category in which states that recognize medical marijuana would utilize to define use of this substance as it is closely linked with medication and is ordered by a physician. It then becomes very easy to link marijuana as a prescription and specifically discuss the guidelines around not allowing any medications affect job performance.

Which leaves the question on recreational drugs which appear to then fit into the category of alcohol as this is a legal drug and when used responsibility and not on the job is permitted. Focusing on the goals encompassing those state and federal laws could also include a specific metric like reduce call-outs and increase days that the workplace is accident free. The definition would also need to include what and how the organization and HRM identifies those covered under the policy all the way to what the employee expectation during off-hours such as a corporate event. It will also be important to understand how to best process to communicate the required information out to all employees and ensure that you have protected confidentiality while ensuring compliance and linking employees with treatment options if needed. Finally, the determination of consequences are necessary so that there clear indications on what is considered a violation. It will be important to measure the level of consequence as determined by a progressive action plan or whether the violation would result in immediate termination. Employees should not have to question where they stand and how non-compliance will affect their employment status.

\section{Testing Methods in the Workplace}

Considerations for how testing methods are determined, the varying degrees of testing and use of testing in the work environment in necessary and critical to HRM. The National Institute on Drug Abuse indicates there are several ways one can conduct drug testing including pre-employment, random testing, reasonable suspicion/cause testing, post-accident testing, return to duty testing and follow-up testing" (NIDA, 2014).

These will be important items to not only consider but also consider in the policy that is to be created. There are five 
potential methods of drug testing which include: urine, blood, sweat, saliva and hair. The one that most are familiar with for most employers is the urine test which is also generally regarded as the cheapest method for testing. It can usually take a few days to one week to receive responses. There are some common things that are tested including PCP, Opiates, Cocaine, Amphetamine and Marijuana and have previously been called the NIDA-5 but is now called the SAMHSA 5 in the industry.

It is extremely important to the process of testing that a provider that is reputable is used and would prefer the company to have various locations in order best serve the employees. It is important to try and understand their fee schedules so you know how much each test will cost the organization.

The most expensive test utilizing hair follicles can check far deeper into the past of an individual and therefore important to know where the company stands as it relates timeframe. It would be best to clearly define that all new hires must go for the urine screen however any workplace accidents require a hair test so that you have a longer view of substance use. Just as important as credibility of your Drug Policy is that the lab is certified with credentials like CLIA (Clinical Laboratory Improvement Amendments) and they are able to show that certain controls are in place to ensure there are no tampering and limited errors.

In looking into the testing of marijuana it can be reviewed by looking at different levels. However, it is almost impossible to connect those levels with actually impaired capacity and most of this is because there are so many different levels in which a person can ingest marijuana ranging from smoking to eating it in a solid or oil form such as butter. Every ingestion can give different responses to the THC levels in urine and blood. Testing only indicates there are some form of exposure and can't precisely place a level or associate it with intoxication as we do when one is tested for alcohol.

There are two ways now in which it would be important to include in testing. The first type of testing is random and typically unannounced. This is a very fair way to administer the testing at the organization without prejudice and while ensuring that employees are not using after their initial drug test. The second way is to ask employees to submit to testing and would occur if there is reasonable suspicion that the employee has used drugs. "The National Institute on Drug Abuse (1991) does consider reasonable suspicion to include observable phenomena (e.g., accounts of actual use, possession, symptoms), abnormal conduct, drug-related investigations (including arrests and convictions), employee drug test tampering, and information from reliable sources" (Mastragelo, 2001).

After a survey was given to a group of substance abuse counselors regarding some of those observable qualities the most common listed for marijuana users was red eyes, poor concentration, loss of time, less energy and perception of distance.

Clearly outlining in the policy the different ways an employee can be tested and that reasonable suspicion is a reason to ask the employee to submit to testing in needed. It needs to be apparent in testing there is a way to appeal or file a grievance of the appeal. While it would be easy to clear an employee who tested positive for a prescribed medicine that contained a narcotic, marijuana is not currently accepted by the federal government as medicine and therefore this would be grounds for immediate termination should the policy exist in this form. Throughout the testing process it is critical to train Human Resources professionals that all results are extremely private and require the utmost confidentiality.

\section{Safety Considerations of Marijuana Use in the Workplace}

The issue of workplace safety is one of the main considerations as it relates to marijuana usage in the workplace. This is one of the major issues seen as a result of drug use is work place accidents. According to the United States Occupational Safety and Health Administration, also known as OSHA, "Of the 17.2 million illicit drug users aged 18 or older in 2005, 12.9 million (74.8 percent) were employed either full or part time. In addition, they found that 10-20 percent of work-related fatalities test positive for drugs or alcohol" (Bradford, 2001).

Understanding there is a direct correlation between a positive test result and workplace accidents gives us an even bigger need to ensure that we utilize drug testing post-accident. There is some very important state legislation around drug testing such as California and the right to privacy of their employees but the state still supports drug testing as a condition of employment, reasonable suspicion and after a workplace accident.

In all of the research, the laws are written in a way that protect the employer and because of this termination of employees due to marijuana is typically done quickly and without issue. Part of building a drug policy is to ensure that HRM builds those consequences of a workplace accident while under the influence of marijuana. Not only does these accidents increase insurance premiums paid by employers but can sometimes render any workers compensation claims non-compensable. In fact, "the National Council on Compensation Insurance Inc. (NCCI) in its paper "High Times in Workers' Comp: The Impact of Medical Marijuana" highlighted medical marijuana as one of the top emerging workers' compensation issues to watch in 2014, with workers' compensation insurance carriers already getting an increasing 
number of requests to pay for prescribed marijuana" (Marti, 2016).

\section{Financial Liability Implications of Workplace Use of Marijuana}

There is certainly a financial impact not only to the claims filed by the employee but also should the cost of prescribing marijuana to help ease pain after a workplace accident. With the difficulty in testing for marijuana levels to even understanding just how safety is really affected by the levels and therefore the policy created must take a zero tolerance around post-accident positive testing. This creates an environment where the employees can feel safe and protected. It will also be important to consider the type of industry in which the human resources director serves as we can see that some jobs such as electrician, truck driver or surgeon would have a very difficult time justifying the use of marijuana during working hours. These are positions that have direct contact with other individuals and just like alcohol or any other drug use on the job is prohibited.

One of the most recent cases is that of Coats v. Dish Network where an employee who was working at the cable company failed a random drug test. While the employee was a quadriplegic and legally prescribed to take marijuana as part of Colorado's Medical Marijuana laws, he was still terminated from his position. The employee won his case as the employee was a telecommuter and did not do one of the positions listed above that would cause harm to others if there was THC in his system. This is important to consider as you determine the consequences of failure of random drug testing. It has been seen that employers are offering the assistance of drug treatment programs while subjecting the employee to future drug tests.

Table 1. State-by-State Laws on Marijuana Use by Citizens

\begin{tabular}{|c|c|c|c|c|}
\hline State & \multicolumn{2}{|c|}{ Legal Status Medicinal } & \multicolumn{2}{|c|}{ Decriminalized State Laws } \\
\hline Alabama & Mixed & Yes & No & View State Laws \\
\hline Alaska & Fully Legal & Yes & Yes & View State Laws \\
\hline Arizona & Fully Legal & Yes & Yes & View State Laws \\
\hline Arkansas & Mixed & Yes & No & View State Laws \\
\hline California & Fully Legal & Yes & Yes & View State Laws \\
\hline Colorado & Fully Legal & Yes & Yes & View State Laws \\
\hline Connecticut & Fully Legal & Yes & Yes & View State Laws \\
\hline Delaware & Mixed & Yes & Yes & View State Laws \\
\hline District of Columbia & Fully Legal & Yes & Yes & View State Laws \\
\hline Florida & Mixed & Yes & No & View State Laws \\
\hline Georgia & Mixed & CBD Oil Only & No & View State Laws \\
\hline Hawaii & Mixed & Yes & Yes & View State Laws \\
\hline Idaho & Fully Illegal & No & No & View State Laws \\
\hline Illinois & Fully Legal & Yes & Yes & View State Laws \\
\hline Indiana & Mixed & CBD Oil Only & No & View State Laws \\
\hline Iowa & Mixed & CBD Oil Only & No & View State Laws \\
\hline Kansas & Fully Illegal & No & No & View State Laws \\
\hline Kentucky & Mixed & CBD Oil Only & No & View State Laws \\
\hline Louisiana & Mixed & Yes & Yes & View State Laws \\
\hline Maine & Fully Legal & Yes & Yes & View State Laws \\
\hline Maryland & Mixed & Yes & Yes & View State Laws \\
\hline Massachusetts & Fully Legal & Yes & Yes & View State Laws \\
\hline Michigan & Fully Legal & Yes & Yes & View State Laws \\
\hline Minnesota & Mixed & Yes & Yes & View State Laws \\
\hline Mississippi & Mixed & Yes & Yes & View State Laws \\
\hline Missouri & Mixed & Yes & Yes & View State Laws \\
\hline Montana & Fully Legal & Yes & Yes & View State Laws \\
\hline Nebraska & Fully Illegal & No & Yes & View State Laws \\
\hline Nevada & Fully Legal & Yes & Yes & View State Laws \\
\hline New Hampshire & Mixed & Yes & Yes & View State Laws \\
\hline New Jersey & Fully Legal & Yes & Yes & View State Laws \\
\hline New Mexico & Mixed & Yes & Yes & View State Laws \\
\hline New York & Fully Legal & Yes & Yes & View State Laws \\
\hline North Carolina & Fully Illegal & No & Yes & $\begin{array}{l}\text { View State Laws } \\
\end{array}$ \\
\hline North Dakota & Mixed & Yes & Yes & View State Laws \\
\hline Ohio & Mixed & Yes & Yes & View State Laws \\
\hline Oklahoma & Mixed & Yes & No & View State Laws \\
\hline Oregon & Fully Legal & Yes & Yes & View State Laws \\
\hline Pennsylvania & Mixed & Yes & No & View State Laws \\
\hline
\end{tabular}




\begin{tabular}{|l|l|l|l|l|}
\hline State & Legal Status & Medicinal & Decriminalized & State Laws \\
\hline Rhode Island & Mixed & Yes & Yes & View State Laws \\
\hline South Carolina & Fully Illegal & No & No & View State Laws \\
\hline South Dakota & Mixed* & Yes & No & View State Laws \\
\hline Tennessee & Fully Illegal & No & No & View State Laws \\
\hline Texas & Mixed & CBD Oil Only & No & View State Laws \\
\hline Utah & Mixed & Yes & No & View State Laws \\
\hline Vermont & Fully Legal & Yes & Yes & View State Laws \\
\hline Virginia & Fully Legal & Yes & Yes & View State Laws \\
\hline Washington & Fully Legal & Yes & Yes & View State Laws \\
\hline West Virginia & Mixed & Yes & No & View State Laws \\
\hline Wisconsin & Mixed & CBD Oil Only & No & View State Laws \\
\hline Wyoming & Fully Illegal & No & No & View State Laws \\
\hline
\end{tabular}

(DISA Global Solutions, 2021)

\section{Methodology}

Research Questions and Hypotheses

Based on the research found in the literature the corresponding research questions and null hypothesis items were developed, as presented below.

Research Question: Should marijuana be protected in workplace environments and under what conditions?

To answer this Research Question the following additional research Questions are posed:

RQ1: Is marijuana a viable medical treatment?

RQ2: Should marijuana be protected under the Federal Family and Medical Leave Act?

RQ3: Should marijuana be protected under the Americans with Disabilities Act?

Hypotheses:

$H_{0} 1$ : Marijuana is not a viable medical treatment.

Hal: Marijuana is a viable medical treatment.

$H_{0}$ 2: Marijuana should not be protected under the Federal Family and Medical Leave Act.

Ha2: Marijuana should be protected under the Federal Family and Medical Leave Act.

$H_{0}$ 3: Marijuana should not be protected under the Americans with Disabilities Act.

Ha3: Marijuana should be protected under the Americans with Disabilities Act.

\section{METHODOLOGY}

\section{Survey Instrument}

A survey questionnaire was taken from the literature, in order to test the hypotheses statements, and to answer the research questions surrounding the issue. The survey was developed based on earlier research conducted by the National Institute of Health (NIH), focused on overall attitudes of US Citizens concerning the use of medical marijuana.

A pilot test was conducted on a random sampling of ten, and the results were tested utilizing the Cronbach Alpha test for reliability. The Cronbach Alpha results indicate a reliability score of 0.894 which indicates a reliable and valid survey instrument to proceed further with data collection and analysis.

\section{Sample and Data Collection}

The responses to the survey produced fifty-seven (57) viable surveys. In order to analyze the data and to test the hypotheses, the participant $\mathrm{N}=57$, was compared against a baseline $\mathrm{N}=57$ where all the data was set to three (3), representing the non-descriptive middle response. The goal of the statistical analysis is to compare the observed median (OM) of actual participant responses to the constructed hypothetical median (HM) of 3, as a test of the null hypothesis statements to determine the statistical significance of the results. The data analysis was via SPSS Version 24, using the One-Sample Wilcoxon Signed Rank Test. It should be noted that, as a standard normal distribution of the data could not be assumed, the nonparametric test was selected for this study. The critical value, z-crit, of 1.645 was obtained via tabulated data charts, within Hogg and Tanis (1993, pp. 682-683). This data is collectively presented in Table 2.

\section{Descriptive Statistics:}

Table 2. One-Sample Wilcoxon Signed Rank Test 
Marijuana Study Participant Responses

One-Sample Wilcoxon Signed Rank Test - Marijuana Study Participant Responses

$[\mathrm{N}=57, \alpha=0.05$, Hypothetical Median $(\mathrm{HM})=3$, z-crit $=1.645]$

\begin{tabular}{|l|l|l|l|l|l|l|}
\hline Question & $\begin{array}{l}\text { Test } \\
\text { Statistic }(T)\end{array}$ & $\begin{array}{l}\text { Standard } \\
\text { Error }\end{array}$ & $\begin{array}{l}\text { Standardized } \\
\text { Test Statistic }(z)\end{array}$ & $\begin{array}{l}\text { Asymtotic Sig, } \\
{[2-\text {-sided test] }(\mathrm{p})}\end{array}$ & $\begin{array}{l}\text { Observed } \\
\text { Median }(\mathrm{OM})\end{array}$ & $\begin{array}{l}\text { Test } \\
\text { Decision }\end{array}$ \\
\hline Q01 & 1596.000 & 118.277 & 6.747 & 0.000 & 5 & Reject Null \\
\hline Q02 & 1256.500 & 103.088 & 5.757 & 0.000 & 5 & Reject Null \\
\hline Q03 & 1311.500 & 106.425 & 5.849 & 0.000 & 4 & Reject Null \\
\hline Q04 & 708.500 & 91.562 & 1.578 & 0.115 & 4 & Retain Null \\
\hline Q05 & 689.500 & 73.844 & 3.507 & 0.000 & 4 & Reject Null \\
\hline Q06 & 1376.500 & 109.474 & 6.038 & 0.000 & 4 & Reject Null \\
\hline Q07 & 873.000 & 85.677 & 4.149 & 0.000 & 4 & Reject Null \\
\hline Q08 & 721.000 & 84.687 & 2.403 & 0.016 & 4 & Reject Null \\
\hline Q09 & 792.500 & 93.931 & 2.177 & 0.029 & 4 & Reject Null \\
\hline Q10 & 878.000 & 99.844 & 2.409 & 0.016 & 4 & Reject Null \\
\hline
\end{tabular}

\section{Findings}

As presented in Table 2, this data leads to the following outlined findings. This is organized by null hypothesis, with applicable survey questions, and a determination of the findings, based on the statistical analysis.

Null Hypotheses $1\left(\mathrm{H}_{0} 1\right)$ states: Marijuana is not a viable medical treatment. This relates to questions 1,2 , and 3 from the survey.

Question 1 is: Have you or someone you know used marijuana for medical purposes. The one-sample Wilcoxon Signed Rank Test indicates that the observed median participant response $(5, \mathrm{~N}=57)$ was significantly different than the hypothetical median of $3, \mathrm{~T}=1596.000, \mathrm{z}=6.747$, and $\mathrm{p}=0.000$ hence the null is rejected.

Question 2 considers: Marijuana has positive medicinal properties. The one-sample Wilcoxon Signed Rank Test denotes that the observed median participant response $(5, \mathrm{~N}=57)$ was significantly different than the hypothetical median of 3 , $\mathrm{T}=1256.500, \mathrm{z}=5.757$, and $\mathrm{p}=0.000$ hence the null is rejected.

Question 3 provides: I would consider the use of medical marijuana to treat a medical condition. The one-sample Wilcoxon Signed Rank Test signifies that the observed median participant response $(4, \mathrm{~N}=57)$ was significantly different than the hypothetical median of $3, \mathrm{~T}=1311.500, \mathrm{z}=5.849$, and $\mathrm{p}=0.000$ hence the null is rejected.

Null Hypothesis $2\left(\mathrm{H}_{0} 2\right)$ states: Marijuana should not be protected under the Federal Family and Medical Leave Act. This connects to questions 4, 5, and 9 from the survey.

Question 4 state: I have taken FMLA Leave. The one-sample Wilcoxon Signed Rank Test represents that the observed median participant response $(4, \mathrm{~N}=57)$ was not significantly different than the hypothetical median of $3, \mathrm{~T}=708.500, \mathrm{z}$ $=1.578$, and $\mathrm{p}=0.115$ hence the null is retained.

Question 5 provisions that: Medical marijuana should be protected under FMLA Leave. The one-sample Wilcoxon Signed Rank Test pinpoints that the observed median participant response $(4, \mathrm{~N}=57)$ was significantly different than the hypothetical median of $3, \mathrm{~T}=689.500, \mathrm{z}=3.507$, and $\mathrm{p}=0.000$ hence the null is rejected.

Question 9 considers if: States should have the right to decide who is covered under FMLA versus the federal government. The one-sample Wilcoxon Signed Rank Test attests that the observed median participant response $(4, \mathrm{~N}=$ 57) was significantly different than the hypothetical median of $3, \mathrm{~T}=792.500, \mathrm{z}=2.177$, and $\mathrm{p}=0.029$ hence the null is rejected.

Null Hypothesis $3\left(\mathrm{H}_{0} 3\right)$ states: Marijuana should not be protected under the Americans with Disabilities Act. This connects to questions $6,7,8$, and 10 from the survey.

Question 6 is: I am familiar with the Americans with Disabilities Act. The one-sample Wilcoxon Signed Rank Test demonstrates that the observed median participant response $(4, \mathrm{~N}=57)$ was significantly different than the hypothetical median of $3, \mathrm{~T}=1376.500, \mathrm{z}=6.038$, and $\mathrm{p}=0.000$ hence the null is rejected. 
Question 7 further considers: I am covered under the ADA. The one-sample Wilcoxon Signed Rank Test expresses that the observed median participant response $(4, \mathrm{~N}=57)$ was significantly different than the hypothetical median of $3, \mathrm{~T}=$ $873.000, \mathrm{z}=4.149$, and $\mathrm{p}=0.000$ hence the null is rejected.

Question. 8 provides that: Medical marijuana should be protected under the ADA. The one-sample Wilcoxon Signed Rank Test illustrates that the observed median participant response $(4, \mathrm{~N}=57)$ was significantly different than the hypothetical median of $3, \mathrm{~T}=721.000, \mathrm{z}=2.403$, and $\mathrm{p}=0.016$ hence the null is rejected.

Question 10 considers that: States should decide who is covered under the ADA versus the federal government. The one-sample Wilcoxon Signed Rank Test points to the observed median participant response $(4, \mathrm{~N}=57)$ was significantly different than the hypothetical median of $3, \mathrm{~T}=878.000, \mathrm{z}=2.409$, and $\mathrm{p}=0.016$ hence the null is rejected.

\section{Limitations of The Study}

This study had a small representative sample. As such it limits the ability to generalize the study to a larger population. Also, the study was focused on the Eastern Coastal area of the United States. This is a regional geographical region, and hence, different results may be achieved from a different geographical area within the United States. Due to the sample size, and geography, the sample for this study may not properly represent the full demographic that could be considered for future research.

In future research, the wording of Question 4 may be reconsidered. There is some indication that the lack of statistically significant results to this question may stem from the wording of the question itself. Or perhaps that the bifurcation of the sample into groups of those who have taken FMLA versus those who have not, a binary choice, may be worth further study in and of itself. Future study may also explore age or generational perceptions of medical marijuana use within the workplace.

\section{Implications for Management}

Key implications for management include those employees consider, increasingly, that marijuana is an acceptable and viable medical treatment option. Employers will need to consider this as a viable option as external forces increase upon the organization. Additionally, the trend is that both FFMLA and ADA will provide employee protections in the area of marijuana use in the foreseeable future.

This will continue to be a current contentious issue as there is a disconnect between States Rights which increasingly allow medical or recreational marijuana use, while Federal Law remains consistently against this same use by citizens. Until this disconnect is resolved leadership of organizations will need to invest time, money, and resources to ensuring visibility on the current status of this issue and conflict and determine how best to handle this at the organizational level. At some point, there should be agreement, legally on this issue, from both State and Federal law perspectives. Citizens will be motivated to vote on this issue, which will continue to keep it on the forefront of societal issues until resolved. However, businesses may face liability, on a case-by-case basis during the current transitional period of time.

Implications for future research include the complexity of the workplace environment. The safety concerns of heavy machinery, or vehicle operation, comprise significant risks within the workplace as to the potential for reduced capacity due to marijuana use. Leaders will need to balance this risk with the potential benefits to employees as their consideration of marijuana as a viable medical treatment connects to workplace demands such as Occupational Safety and Health Administration (OSHA) requirements. Future research may consider the implication of law, and OSHA, as influencing elements of senior leader decision-making. It also may consider employee voice as an element of corporate policymaking, in this important medical and business intersection of pragmatic reality.

\section{HRM Considerations and Responsibilities}

As an HR professional the appearance of a safety violation is far worse than the employee uses medical marijuana recommended by a physician. Therefore, as an employer, there is a responsibility when it comes to safety in the workplace.

The main responsibility is education and an open and healthy dialogue about the dangers of intoxication at the workplace. Within the standards of conduct and policies there should be clear guidance for employees so they understand how their actions have consequences. It will be important to establish a clear method for communicating educational materials in a public place along with any treatments options that you would like to offer the employee.

As HRM professionals, what can be done in the case of marijuana use as it relates to the legalization of medical and recreational marijuana is to continue to focus on the fact that the drug is still considered not legal in the eyes of the federal government. While still respecting the policies of the state, there should be specific language that addresses marijuana use on the job and impaired judgment as a result. 
It should be categorized in the same category as prescription medicine and the policy should be straight forward and without question. As long as there is clear distinction in the policy that separates between working hours and off hours and encourages treatment should the employee needed assistance you are representing the company and its values.

Safety should be a top concern in the policy and focus on the safety of others on the job. Continuing to review articles, legislation and court cases will help you to modify the policy as needed since this is sure to be a changing landscape for drug-free workplaces.

\section{Conclusion}

The concern over marijuana use in the workplace will continue to grow in complexity for business decision-making until State Law and Federal Law agree. The United States population of citizens continues to have a pro-marijuana stance on issues as a trend. As such, voting will change policy over long-term, as representative government responds to citizen input. Businesses will continue to invest effort to keep appraised of current status of regulation, as it transitions. This in turn, will impact the organization from leadership, human resources, and project management perspectives as extra effort, time, money, and resources are expended, and greater-than-normal effort is focused on handling concerns on a case-by-case basis until law is set and a new status quo established.

This research has focused on the key areas when it comes to marijuana in the workplace and their implications for HR management of policies and procedures to address this drug use. . The fundamental belief that we need to have clear and defined policies on marijuana usage. Currently the laws are written in a way that are very employer friendly and allow for protection under federal statutes and the classification by the Drug Enforcement Agency as reasons for the policy.

The policy should be easily understandable and be communicated to employees not just during the orientation onboarding process but periodically during annual education and training seminars. Including it in the organization's Code of Conduct and having this signed each year by all employees ensures the employee has had the opportunity to read, understand and ask questions if necessary.

Secondly focus was on testing and the different ways that a company can chose to test employees. Costs associated with each method of testing as well as on the levels of usage marijuana that would cause a positive result. Three different ways in which you can chose to test your employees including condition of employment (pre-hire), random sampling and also suspected intoxication. The signs that can be exhibited in an employee who has been ingesting marijuana. We reviewed the research on safety concerns when employees use marijuana at work. It is necessary to understand the importance of a safe work environment including the effects to workers compensation should the occurrence of work place accidents rise.

Overall, focusing on these three topics has allowed for potential informed decisions about how one should handle the ever-changing scope of this drug. Understanding these topics and drawing conclusions based on current court cases helps us to logically start to set up for some situational experiences and then to watch these very cases as they start to play out in our legal system. This is an ongoing and continually changing topic as HR professionals continue to discuss and learn from how the courts rule on this social process.

For now, this study has helped determine that employees do see marijuana as a viable medical treatment, worthy of employer consideration as implications connect to the workplace. While support for FMLA lacked in some areas, such as individual participant implementation in their own professional lives, there was support for FMLA and ADA implementation in these areas to protect employees within the workplace.

\section{About the authors:}

Dr. Steven Cates is a Graduate Professor of Human Resources Management at the Purdue Global Graduate School of Business and IT. His research interests are employment discrimination, Employment and Labor Law, Millennials, and Generation Z employees.

Wendy N. Buice is a MSML graduate from the Purdue University Global Graduate School of Business and IT.

\section{References}

Bell, J. D. (2018). Navigate Workers' Medical and Recreational Use of Marijuana. Retrieved from https://www.shrm.org/ResourcesAndTools/legal-and-compliance/state-and-local-updates/Pages/CA-medical-recrea tional-use-marijuana.aspx

Brodwin, E. (2018). A mysterious syndrome in which marijuana users get violently ill is starting to worry researchers. Retrieved from http://a.msn.com/05/en-us/BBJbiHz?ocid=se

Dean, J. (2018). America Is Giving Away the $\$ 30$ Billion Medical Marijuana Industry. Retrieved from https://www.bloomberg.com/news/features/2018-03-07/america-is-giving-away-the-30-billion-medical-marijuana-i ndustry 
Deschenaux, J. (2014). Marijuana Use and Workplace Drug Policies: SHRM. Retrieved from https://www.shrm.org/ResourcesAndTools/legal-and-compliance/state-and-localupdates/Pages/Marijuana-Use-Wor kplace-Drug-Policies.aspx

Develop A Policy. (2016). Programs and Campaigns Drug-Free Workplace ToolKit, Substance Abuse and Mental Health Services Administration SAMHSA. Retrieved from http://www.samhsa.gov/workplace/toolkit/develop-policy

Dohery, J. (2017), Medical marijuana in the Workplace, Inspiring HR. Retrieved from https://inspiringhr.com/medical-marijuana-in-the-workplace/

Dougherty, T. (2016). Marijuana Use and Its Impact on Workplace Safety and Productivity Occupational Health and Safety. Retrieved from

https://ohsonline.com/articles/2016/02/01/marijuana-use-and-its-impact-on-workplacesafety-and-productivity.aspx

Drug Testing and Workplace Issues. (2014). National Institute on Drug Abuse. Retrieved from https://www.drugabuse.gov/related-topics/drug-testing

Federal Executive Order (1986). Drug Free Federal Workplace Order 1256451 FR 32889, 3CFR, 1986 Comp., p.224 Retrieved from https://www.archives.gov/federal register/codification/executive-order/12564.html

The Five Drug Testing Methods and What Expect (2016). Parenting Teens, Substance Abuse and Mental Health Services Administration SAMHSA. Retrieved from https://www.verywell.com/drug-testing-methods-2606200

Fisher, M. (2016) Marijuana: Legalizing Medical, Recreational Use Has implications for Workplace Drug Use Policies California Chamber of Commerce. Retrieved from http://advocacy.calchamber.com/wp-content/uploads/policy/issue-reports/WorkplaceSafety-Marijuana-2016.pdf

Gonzalez, R. (2017). The Future of Weed Science is a Van in Colorado. Retrieved from https://www.wired.com/story/the-future-of-weed-science-is-a-van-in-colorado/

Gonzales v Raich, 545, US, 1 (2005). https://doi.org/10.1086/655193

Guidelines for the Implementation of a Drug-Free workplace policies and programs for the private sector, Comprehensive Dangerous Drug Act of 2002 Order No. 53-03. Retrieved from http://www.chanrobles.com/doledepartmentorderno53-03seriesof2003.html\#.WCjff7ruUk

Hogg, R., \& Tanis, E. (1993). Probability and statistical inference (4th ed.). New York Macmillan Publishing Company.

Hughes, T. (2018). Marijuana industry poised for supercharged growth thanks to President Trump. Retrieved from http://a.msn.com/00/en-us/AAw6fvg?ocid=se

JazzHR (Producer). (2017). Getting the straight dope: Navigating medical marijuana in the workplace. Retrieved from https://www.youtube.com/watch?v=ULaY8Erdos4

Marijuana (A9 - Tetrahydrocannabinol). Drugs and Human Performance Fact Sheets. National Highway Traffic and Safety Commission. Retrieved from http://www.nhtsa.gov/PEOPLE/INJURY/research/job185drugs/cannabis.htm

Mastrangelo \& Mcdonald. (2001). Defining "Reasonable Suspicion” of Employee Drug Use The Symptoms of Drug Impairment Checklist. University of Baltimore. Retrieved from http://www.xavier.edu/appliedhrmresearch/2001Summer/MS\%206_1_\%20Mastrengelo.pdf

Nagele-Piazza, L. (2018a). Can California Employers Still Test for Marijuana? Retrieved from https://www.shrm.org/ResourcesAndTools/legal-and-compliance/state-and-localupdates/Pages/Can-California-Em ployers-Still-Test-for-Marijuana.aspx

Nagele-Piazza, L. (2018b). Vermont Legalizes Recreational Marijuana: Employers can still discipline intoxicated workers. Retrieved from

https://www.shrm.org/ResourcesAndTools/legal-and-compliance/state-and-localupdates/Pages/Vermont-LegalizesRecreational-Marijuana.aspx

Nagele-Piazza, L. (2018c). How Do Recreational Marijuana Laws Affect the Workplace? Retrieved from https://www.shrm.org/ResourcesAndTools/legal-and-compliance/stateand-local-pdates/Pages/Recreational-Marijua na-Laws-Workplace-Employment.aspx

NORML.org. (2018). State Info: United States. National Organization for the Reform of Marijuana Laws Foundation.

Simon, M. (2018a). The Dirty Secret of California's Cannabis: It's Dirty. Retrieved from https://www.wired.com/story/california-cannabis/

Simon, M. (2018b). Why no gadget can prove how stoned you are. Retrieved from 
https://www.wired.com/story/why-no-gadget-can-prove-how-stoned-you-are

Smith, A. (2018). Employers Increasingly Drop Marijuana Testing of Job Applicants. Retrieved from https://www.shrm.org/ResourcesAndTools/legal-and-compliance/employment-law/Pages/less-marijuana-testing.as px

State Medical Marijuana Laws (2021, 2016). Retrieved September 20,2021, and October 5, 2016, from http://www.ncsl.org/research/health/state-medical-mariiuana-laws.aspx.

Department of Transportation, Regulations on Medical marijuana. (2018). Retrieved from https://www.transportation.gov/odapc/medical-marijuana-notice

US Supreme Court v. Oakland Cannabis Buyers 532 U.S. 483 (2001). Retrieved from https://supreme.justia.com/cases/federal/us/532/483/case.html

Williams, S. (2018). Marijuana: A $\$ 75$ Billion Market by 2030? Retrieved from https://www.fool.com/investing/2018/04/15/marijuana-a-75-billion-market-by-2030.aspx

Workplace Accidents And Drug Abuse. (2001). Bradford Health Services. Retrieved from https://bradfordhealth.com/workplace-accidents-drug-alcohol-abuse/

\section{APPENDIX I}

SURVEY

This research project is about your opinion on Medical Marijuana Please read each of the following questions carefully. Please circle that number that most closely reflects your actual response to that question. Please be honest with your responses. These responses will be held confidential and will not identify you in any way. Thank you for responding to these questions. You will note your responses can be from Strongly Agree to Strongly Disagree. If you have no opinion, please circle the number " 3 " or $\mathrm{N}$ for Neutral.

Have you or someone you know used marijuana for medical purposes?

$\begin{array}{lllll}\text { SD } & \text { D } & \text { N } & \text { A } & \text { SA } \\ 1 & 2 & 3 & 4 & 5\end{array}$

Marijuana has positive medicinal properties.

$\begin{array}{lllll}\text { SD } & \text { D } & \text { N } & \text { A } & \text { SA } \\ 1 & 2 & 3 & 4 & 5\end{array}$

I would consider the use of medical marijuana to treat a medical condition

$\begin{array}{lllll}\text { SD } & \text { D } & \text { N } & \text { A } & \text { SA } \\ 2 & 3 & 4 & 5 & \end{array}$

I have e taken FMLA Leave

$\begin{array}{lllll}\mathrm{SD} & \mathrm{D} & \mathrm{N} & \mathrm{A} & \mathrm{SA} \\ 1 & 2 & 3 & 4 & 5\end{array}$

Medical marijuana should be protected under FMLA Leave

$\begin{array}{lllll}\text { SD } & \text { D } & \text { N } & \text { A } & \text { SA } \\ 1 & 2 & 3 & 4 & 5\end{array}$

I am familiar with the Americans with Disabilities Act
SD
D
$\mathrm{N}$
A
SA 


$\begin{array}{lllll}1 & 2 & 3 & 4 & 5\end{array}$

I am covered under the ADA

$\begin{array}{lllll}\text { SD } & \text { D } & \text { N } & \text { A } & \text { SA } \\ 1 & 2 & 3 & 4 & 5\end{array}$

Medical marijuana should be protected under the ADA

$\begin{array}{lllll}\text { SD } & \text { D } & \text { N } & \text { A } & \text { SA } \\ 1 & 2 & 3 & 4 & 5\end{array}$

States should have the right to decide who is covered under FMLA versus the federal government

$\begin{array}{lllll}\text { SD } & \text { D } & \text { N } & \text { A } & \text { SA } \\ 1 & 2 & 3 & 4 & 5\end{array}$

States should decide who is covered under the ADA versus the federal government.

$\begin{array}{lllll}\text { SD } & \text { D } & \text { N } & \text { A } & \text { SA } \\ 1 & 2 & 3 & 4 & 5\end{array}$

\section{Copyrights}

Copyright for this article is retained by the author(s), with first publication rights granted to the journal.

This is an open-access article distributed under the terms and conditions of the Creative Commons Attribution license which permits unrestricted use, distribution, and reproduction in any medium, provided the original work is properly cited. 